\title{
Retraction Note: Evaluation of air pollutants based on embedded system and PPP project performance factors
}

\author{
Mei $\mathrm{Lu}^{1} \cdot \operatorname{Ning~} \mathrm{Li}^{1}$
}

Published online: 13 December 2021

C) Saudi Society for Geosciences 2021

Retraction Note to: Arabian Journal of Geosciences (2021) 14: 1543 https://doi.org/10.1007/s12517-021-07948-w

The Editor-in-Chief and the Publisher have retracted this article because the content of this article is nonsensical. The peer review process was not carried out in accordance with the Publisher's peer review policy. The authors have not responded to correspondence regarding this retraction.

The original article can be found online at https://doi.org/10.1007/ s12517-021-07948-w.

Mei Lu

Ningch0616@126.com

1 School of Management, Xi' an University of Architecture and Technology, Xi' an 710055, Shaanxi, China 